\title{
PENERAPAN MODEL PEMBELAJARAN CONTEXTUAL TEACHING AND LEARNING, QUANTUM TEACHING TERHADAP MOTIVASI BERPRESTASI DAN HASIL BELAJAR IPS SISWA KELAS VII
}

\author{
Ni Nyoman Sari Astiti ${ }^{1}$, I Wayan Lasmawan², lyus Akhmad Haris³. \\ Program Studi Pendidikan IPS Universitas Pendidikan Ganesha Singaraja \\ e-mail: sariastiti40@gmail.com¹ ${ }^{1}$ lasmawanizer@yahoo.com ${ }^{2}$, tanishadi1@gmail.com³
}

\begin{abstract}
Abstrak
Penelitian ini adalah penelitian eksperimen semu, dengan rancangan post test only control group design, bertujuan untuk mengalisis perbedaan motivasi berprestasi dan hasil belajar IPS antara siswa yang mengikuti pembelajaran contextual teaching and learning dan quantum teaching siswa kelas VII, secara terpisah maupun simultan. Populasi dalam penelitian ini adalah semua siswa kelas VII. Setelah diadakan uji kesetaraan, diplih secara random 2 kelas sebagai sampel, 1 kelas menjadi kelas ekspeimen dan 1 kelas sebagai kelas kontrol. Data dalam penelitian dikumpulkan dengan kuesioner dan tes hasil belajar IPS dan dianalisis dengan anava dan manova. Hasil analisis menunjukkan bahwa: (1) ada perbedaan motivasi berprestasi siswa antara yang mengikuti pembelajaran dengan model pembelajaran Contextual Teaching and Learning dan Quantum Teaching dengan $F_{\text {hitung }}=52,613(p=0,000<0,05)$, (2) ada perbedaan hasil belajar IPS siswa antara yang mengikuti pembelajaran dengan model pembelajaran Contextual Teaching and Learning dan Quantum Teaching dengan Fhitung $=30,384(p=0,000<0,05)$, dan (3) terdapat perbedaan motivasi berprestasi dan hasil belajar IPS siswa antara yang mengikuti pembelajaran dengan model pembelajaran Contextual Teaching and Learning dan Quantum Teaching dengan F- Wilks' Lambda = 48,307 ( $p=0,000<0,05$ ). Dengan demikian dapat disimpulkan bahwa model pembelajaran Contextual Teaching and Learning dan Quantum Teaching berpengaruh signifikan terhadap motivasi berprestasi dan hasil belajar siswa kelas VII.
\end{abstract}

Kata kunci: model pembelajaran contextual teaching and learning dan quantum teaching, motivasi berprestasi, hasil belajar IPS

Abstract
This study aims to determine differences in achievement motivation and IPS learning outcomes between students who follow the learning with contextual teaching and learning learning model and quantum teaching in grade VII in separate or simultaneous. The population in this study are all students of class VII. Taken by random two classes as sample of research. Data were collected by questionnaire and IPS learning result test and analyzed by anava with $F$ and manova test with F-Wilks' Lambda test. The result of the analysis shows that: (1) there is difference of achievement motivation among students who follow the learning with Contextual Teaching and Learning model and Quantum Teaching in grade VII with $F$ count $=52,613(p=0,000<0,05), 2)$ there is difference of learning result of IPS student between follow learning with learning model Contextual Teaching and Learning and Quantum Teaching at student of class VII with F count $=30,384(p=0,000<0,05)$, and (3) there is difference achievement motivation and learning outcomes of IPS students between those who followed the learning with Contextual Teaching and Learning model and Quantum Teaching in grade VII with F-Wilks' Lambda $=48,307(p=0,000<0.05)$. Thus it can be concluded that the learning model Contextual Teaching and Learning and Quantum Teaching have a significant effect on achievement motivation and student learning outcomes of grade VII.

Keywords: learning contextual teaching and learning model and quantum teaching, achievement motivation, IPS learning result.

\section{PENDAHULUAN}

Guru merupakan salah satu unsur pembelajaran yang berperan penting terhadap terwujudnya proses dan hasil yang dapat mengantarkan siswa ke arah tujuan pembelajaran yang telah ditetapkan. Salah satu tugas guru adalah menciptakan suasana pembelajaran yang menarik dan menyenangkan serta dapat menunjang tercapainya tujuan. Hasil pembelajaran dapat terwujud jika guru mampu menyelenggarakan proses pembelajaran 
secara efektif. Efektifitas hasil pembelajaran akan dicapai manakala guru memiliki kompetensi pedagogik, profesional, kepribadian, dan sosial yang berkualitas.

Berdasarkan hasil uji kompetensi guru yang diselenggalakan kemdikbud tahun tahun 2015 menunjukkan bahwa kompetensi guru belum sesuai dengan harapan. Uji kompetensi guru tahun 2015 melibatkan 2.430.427 guru, menunjukkan rata-rata nasional belum mencapai target, yakni 53,05 dari target 55. Nilai kemampuan profesional 54,77; sedangkan nilai rata-rata kompetensi pedagogik 48.94. Hanya ada 7 provinsi yang mencapai nilai ratarata nasional, yakni Daerah Istimewa Yogyakarta $(62,58)$, Jawa Tengah $(59,10)$, DKI Jakarta $(58,44)$, Jawa Timur $(56,73)$, Bali $(56,13)$, Bangka Belitung $(55,13)$, dan Jawa Barat $(55,06)$. Terendah rata-rata di salah satu provinsi di luar Jawa, hanya mencapai angka 41,96 (Kemendikbud, 2016). Hasil Uji Kompetensi Guru (UKG) dapat digunakan sebagai refleksi kualitas guru Indonesia. Sementara itu, Dirjen Guru dan Tenaga Kependidikan menyatakan bahwa target nilai rata-rata UKG tahun 2016 sebesar 65, sehingga menuntut upaya dan kerja keras guna pencapaiannya. Upaya peningkatan kualitas harus dilakukan, antara lain dengan penyiapan guru professional melalui penyelenggaraan pendidikan penghasil guru yakni di LPTK. (http://www.kemdikbud.go.id/ diakses tanggal 12 Juni 2017).

Informasi di atas juga sesuai dengan apa yang dinyatakan Yulianti (2015) bahwa kebanyakan guru belum sepenuhnya menguasai metode mengajar. Metode pembelajaran yang banyak dilakukan oleh guru-guru IPS terpadu adalah metode ceramah berdasarkan teks. Pada metode ini, siswa mendengarkan dan mencatat materi yang dijelaskan guru di depan kelas melalui metode ceramah. Hal ini akan berpengaruh kepada hasil belajar siswa, di mana hasil didapatkan kemungkinan jauh dari harapan.Hal ini sejalan dengan Fitriani (2015) kesulitan dalam pembelajaranguru dalam pembelajaran IPS yaitu (1) penguasaan materi yang tergabung dalam IPS, kesulitan dalam penguasaan konsep pembelajaran terpadu dan pengembangan pembelajaran, (2) menggunakan dan memilih media dan sumber belajar yang cocok, (3) menggunakan metode pembelajaran bervariasi, serta kesulitan memilih metode yang sesuai dengan materi (4) Membuat pemetaan pembelajaran tematik. Dari kesulitan-kesulitan tersebut, pengembangan pembelajaran merupakan suatu kesulitan yang telah dialami oleh para guru-guru IPS.

Berdasarkan hasil observasi yang dilakukan oleh peneliti awal bulan Oktober 2017 di SMP Negeri 1 Kediri, menunjukkan metode yang digunakan guru kurang variatif, pembelajaran terpusat pada guru yang mengakibatkan motivasi berprestasi dan hasil belajar IPS khususnya kelas VII kurang optimal. Metode seperti ini mengakibatkan siswa cepat bosan dan menurunkan motivasi siswa untuk belajar. Dilihat dari ketercapaiaan KKM, tampak masih banyak siswa belum mencapai KKM. Masih banyaknya siswa yang belum mencapai KKM, perlu diidentifikasi faktor yang menyebabkan. Salah satu faktor yang diduga berpengaruh terhadap motivasi berprestasi dan hasil belajar siswa dalah adalah cara guru dalam penyampaian materi pembelajaran yang hanya berpaku pada model-model pembelajaran konvensional. Untuk itu perlu dilakukan penelitian model pembelajaran Contextual Teaching Learning dan Quantum Teaching untuk meningkatkan hasil belajar siswa.

Salah satu variabel yang perlu ditingkatkan dalam pembelajaran adalah motivasi berprestasi siswa. Menurut McClelland (dalam Martaniah, 1984:20) mendefinisikan motivasi berprestasi sebagai suatu usaha untuk mencapai sukses, yang bertujuan untuk berhasil dalam kompetisi dengan suatu standar keunggulan. Ukuran keunggulan ini dapat berupa prestasi diri sendiri maupun prestasi orang lain. Orang yang mempunyai motivasi berprestasi yang tinggi menurut pendapatnya, mempunyai sikap yang positif terhadap situasi berprestasi. Seseorang yang mempunyai motivasi berprestasi tinggi akan dapat lebih berprestasi dalam situasi di mana ia dapat berpacu dengan ukuran keunggulan yang diinternalisasikan, dan prestasinya akan lebih baik jika dapat mengembangkan kreativitasnya. Kesenangan yang didapat seseorang yang mempunyai motivasi berprestasi yang tinggi diperoleh dari keberhasilannya melakukan perbuatannya yang sukses.Di lain pihak motivasi berprestasi pada dasarnya adalah program untuk mencapai suatu pekerjaan atau untuk berprestasi yang dimiliki oleh seorang individu (Sukari, 1999:56). Motivasi 
berprestasi dalam diri individu ditandai dengan munculnya keinginan untuk memperoleh keunggulan dalam melaksanakan setiap kegiatan. Dengan perkataan lain, orang yang memiliki motivasi berprestasi tinggi akan selalu berupaya agar setiap kegiatan yang dilaksanakan mencapai hasil yang terbaik. Agar sukses, seseorang memerlukan ketekunan, inisiatif, dan berani mengambil resiko. Dalam usaha meningkatkan motivasi berprestasi siswa perlu diujicobakan model pembelajaran yang inovatif, yakni: model pembelajaran Contextual Teaching and Learning dan Quantum Teaching.

Model pembelajaran yang efektif guna mencapai pembelajaran yang optimal adalah Contextual Teaching and Learning. Pendekatan Contextual Teaching and Learning (CTL) merupakan konsep belajar yang membantu guru mengkaitkan materi (content) yang diajarkan dengan situasi dunia nyata (Nurhadi, 2003:52). Dengan adanya pengkaitan materi tersebut akan mendorong siswa dalam membuat hubungan antara pengetahuan yang dimiliki dengan implementasi dalam kehidupan mereka dalam keluarga dan masyarakat. Sistem CTL merupakan suatu proses pendidikan yang bertujuan membantu siswa melihat makna dalam bahan pelajaran yang mereka pelajari dengan cara menghubungkannya dengan konteks kehidupan mereka sehari- hari, yaitu konteks lingkungan pribadi, sosial dan budaya (Nurhadi, 2003:53).

Selain CTL, model pembelajaran yang dapat meningkatkan motivasi berprestasi dan hasil belajar siswa adalah Quantum Teaching, Quantum Teaching adalah pengubahan bermacam-macam interaksi yang ada di dalam dan di sekitar momen belajar. Interaksiinteraksi ini mencakup unsur-unsur untuk belajar efektif yang mempengaruhi kesuksesan siswa. Interaksi-interaksi ini mengubah kemampuandan bakat alamiah siswa menjadi cahaya yang akan bermanfaat bagi merekasendiri dan bagi orang lain (DePorter, 2010:34). Quantum teaching, guru dapat mengajar dengan memfungsikan kedua belahan otak kiri dan otak kanan pada fungsinya masing-masing. Penelitian di Universitas California mengungkapkan bahwa masing-masing otak tersebut mengendalikan aktivitas intelektual yang berbeda. Otak kiri menangani angka, susunan, logika, organisasi, dan hal lain yang memerlukan pemikiran rasional, beralasan dengan pertimbangan yang deduktif dan analitis. Bagian otak ini yang digunakan berpikir mengenai hal-hal yang bersifat matematis dan ilmiah. Kita dapat memfokuskan diri pada garis dan rumus, dengan mengabaikan kepelikan tentang warna dan irama.

Otak kanan mengurusi masalah pemikiran yang abstrak dengan penuh imajinasi. Misalnya warna, ritme, musik, dan proses pemikiran lain yang memerlukan kreativitas, orisinalitas, daya cipta dan bakat artistik. Pemikiran otak kanan lebih santai, kurang terikat oleh parameter ilmiah dan matematis. Kita dapat melibatkan diri dengan segala rupa dan bentuk, warna-warni dan kelembutan, dan mengabaikan segala ukuran dan dimensi yang mengikat. Quantum teaching diarahkan untuk proses pembelajaran di kelas, pada saat berhadapan dengan siswa, merencanakan pembelajaran, dan mengevaluasinya. Pola quantum terangkum dan TANDUR (https://www.kompasiana.com diakses tanggal 12 Januari 20018).

\section{METODE PENELITIAN}

Penelitian ini dikatagorikan eksperimen semu (quasi experiment). Desain ini dipilih karena eksperimen dilakukan di beberapa kelas tertentu dengan siswa yang telah ada atau sebagaimana adanya. Rancangan eksperimen yang dipilih adalah rancangan post test only control group design. Populasi dalam penelitian ini adalah semua siswa kelas VII SMP Negeri 1 Kediri yang terdiri dari empat belas kelas yang setara. Keempat belas kelas ini adalah setara secara administrasi karena pembentukan kelas dilakukan di sekolah ini disebarkan secara merata siswa memiliki kemammpuan tinggi, sedang dan rendah. Selain itu, kesetaraan juga dilakukan dengan uji statistik. Hasil uji statistik berdasarkan nilai ulangan IPS pada semester sebelumnya diperoleh bahwa keempat belas kelas dinyatakan relatif setara. Karena semua kelas secara, maka diambil secara random dua kelas sebagai sampel penelitian, satu kelas sebagai kelas eksperimen dan satu kelas sebagai kelas kontrol. Kelas ekperimen diberi perlakukan pembelajan dengan CTL dan kelas kontrol dengan quantum 
teaching. Data motivasi berprestasi dikumpulkan dengan kuesioner dengan model sakala Likert, yang telah diuji pakar (judges) dan uji empiris validitas dan reliabilitasnya. Hasil belajar siswa diukur dengan tes hasil belajar IPS dalam bentuk pilihan ganda yang telah diuji pakar dan empiris. Data hasil pengukuran dianlisis dengan dianalisis dengan anava dengan uji F dan manova dengan uji F- Wilks' Lambda, dengan terlebih dahulu diuji prasyarat, yaitu: uji normalitas ebaran data, homogenitas varians, dan homogenitas matriks varians.

\section{HASIL PENELITIAN DAN PEMBAHASAN}

\section{Pengujian Hipotesi Pertama}

Berdasarkan hasil analisis dengan analisis varians satu jalur diperoleh bahwa nilai $F_{\text {hitung }}$ $=52,613(p=0,000<0,05)$. Oleh karena itu, hipotesis nol $(\mathrm{Ho})$ yang menyatakan bahwa tidak perbedaan motivasi berprestasi siswa antara yang mengikuti pembelajaran dengan model pembelajaran Contextual Teaching and Learning dan Quantum Teaching pada s siswa kelas VII SMP Negeri 1 Kediri ditolak. Jadi, ada perbedaan motivasi berprestasi siswa antara yang mengikuti pembelajaran dengan model pembelajaran Contextual Teaching and Learning dan Quantum Teaching pada siswa kelas VII SMP Negeri 1 Kediri.

Hasil perhitungan menunjukkan bahwa perbedaan motivasi berprestasi siswa yang mengikuti pembelajaran dengan model pembelajaran Contextual Teaching and Learning pada siswa kelas VII SMP Negeri 1 Kediri dengan skor rata-rata 169,433, sedangkan motivasi berprestasi siswa yang mengikuti pembelajaran dengan pembelajaran Quantum Teaching pada siswa kelas VII SMP Negeri 1 Kediri dengan skor rata-rata 147,500. Ternyata skor rata-rata motivasi berprestasi siswa yang mengikuti pembelajaran dengan model pembelajaran Contextual Teaching and Learning lebih tinggi daripada siswa yang mengikuti pembelajaran dengan pembelajaran Quantum Teaching pada siswa kelas VII SMP Negeri 1 Kediri. Dengan demikian, dapat disimpulkan motivasi berprestasi siswa yang mengikuti pembelajaran dengan model pembelajaran Contextual Teaching and Learning lebih tinggi daripada siswa yang mengikuti pembelajaran dengan pembelajaran Quantum Teaching pada siswa siswa kelas VII SMP Negeri 1 Kediri.

Contextual Teaching and Learning (CTL) merupakan proses pembelajaran yang holistik dan bertujuan membantu siswa untuk memahami makna materi ajar dengan mengaitkannya terhadap konteks kehidupan mereka sehari-hari (konteks pribadi, sosial dan kultural), sehingga siswa memiliki pengetahuan/ keterampilan yang dinamis dan fleksibel untuk mengkonstruksi sendiri secara aktif pemahamannya (Bandono, 2008). Selanjutnya menurut Sardiman (2010: 223), untuk penerapannya ada tujuh komponen utama dalam pembelajaran CTL yaitu konstruktivisme (constructivism), menemukan (inquiry), bertanya (questioning), masyarakat belajar (learning community), pemodelan (modelling), refleksi (reflection) dan penilaian sebenarnya (authentic assesment). Untuk mencapai tujuan tersebut terdapat delapan komponen yang harus terpenuhi sebagai berikut: (1) membuat keterkaitanketerkaitan yang bermakna (making meaningful connections), (2) melakukan pekerjaan yang berarti (doing significant work), (3) melakukan pembelajaran yang diatur sendiri (self regulated learning), (4) melakukan kerja sama (collaborating), (5) berpikir kritis dan kreatif (critical and creative thinking), (6) membantu individu untuk tumbuh dan berkembang (nurturing the individual), (7) mencapai standar yang tinggi (reaching high standards), dan (8) menggunakan penilaian autentik (using authentic assessment).

Banyak cara efektif untuk mengaitkan pengajaran dan pembelajaran dengan konteks situasi sehari-hari siswa. Setidaknya enam cara berikut ini dapat ditempuh: (1) menghubungkan pembahasan konsep nilai-nilai inti etika sebagai landasan karakter dengan keseharian siswa, (2) memasukan materi dari bidang lain di dalam kelas, (3) dalam mata pelajaran yang tetap terpisah terdapat topik-topik yang saling berhubungan, (4) mata pelajaran gabungan yang menyatukan isu-isu moral, (5) menggabungkan sekolah dan pekerjaan, (6) penerapan nilai-nilai moral yang dipelajari di sekolah ke masyarakat. Implementasi dari langkah keenam ini menunjukkan bahwa para siswa mempunyai kemampuan luar biasa untuk mencapai standar pendidikan dan standar etika yang tinggi jika mereka melihat mengapa hal yang mereka lakukan itu penting. 
Metode pembelajaran merupakan salah satu cara yang digunakan guru dalam mengadakan komunikasi dengan siswa pada saat berlangsungnya pembelajaran. Menurut Akhmad Sudrajat (2008) metode pembelajaran dapat diartikan sebagai cara yang digunakan untuk mengimplementasikan rencana yang sudah disusun dalam bentuk kegiatan nyata dan praktis untuk mencapai tujuan pembelajaran. Peranan metode pembelajaran sebagai alat untuk menciptakan proses pembelajaran sangatlah penting. Dengan model pembelajaran diharapkan terciptalah interaksi edukatif. Dalam upaya itu maka penerapan model pembelajaran CTL dalam pendidikan karakter menghendaki adanya pembelajaran mandiri dan kerja sama. Pada tahap ini yang dikondisikan untuk dilakukan siswa adalah siswa belajar langsung dengan mencari dan menggabungkan informasi secara aktif dari masyarakat maupun ruang kelas. Selanjutnya siswa dirangsang untuk mengajukan pertanyaan-pertanyaan menarik seputar lingkunganna. Pertanyaan-pertanyaan ini akan membantu siswa untuk menemukan kaitan antara pelajaran di kelas dan situasi yang mereka alami baik di sekolah, di rumah, maupun sebagai anggota masyarakat. Kemudian siswa diberi kesempatan membuat pilihan sendiri dalam menentukan keterlibatan mereka dalam permasalahan karakter yang dipelajari. Dan pada akhirnya siswa mampu membentuk kesadaran diri, yaitu kemampuan merasakan perasaan pada saat perasaan itu muncul. Siswa dilatih untuk bersikap kritis terhadap isu-isu moral yang terjadi dengan mengajukan tiga pertanyaan berikut: prinsip-prinsip apa yang dijadikan tuntunan dalam kehidupan seharihari, kewajiban apa yang timbul dari hubungan-hubungan siswa dengan yang lain, apa konsekuensi yang didapatkan dari keputusan dan tindakan yang diambil. Pertanyaanpertanyaan ini mengajarkan siswa untuk menunjukkan tanggung jawab moral sebagai anggota masyarakat.

Penerapan pembelajaran model pembelajaran CTL ini dapat meningkatkan motivasi berprestasi siswa dalam kegiatan belajar mengajar. Guru merencanakan secara matang skenario pembelajaran yang sesuai dengan materi yang diajarkan sehingga dapat mengubah peran guru dari teacher centeredmenjadi student oriented. Pembelajaran dengan pendekatan kontekstual akan menciptakan siswa menjadi peserta aktif bukan hanya pengamat yang pasif dan bertanggung jawab terhadap belajarnya. Penerapan pembelajaran kontekstual akan memotivasi siswa untuk membentuk hubungan antara pengetahuan dan aplikasinya dengan kehidupan mereka sebagai anggota keluarga, warga masyarakat dan warga negara. Peran aktif siswa tidak terbatas hanya aktifitas pikir melainkan juga rasa dan emosional, karena siswa lebih dekat dan lebih menghayati, serta akrab dengan hal yang sedang dipelajari. Dengan demikian maka hasil belajar yang dicapai siswa akan lebih bermakna dengan penerapan pendekatan kontekstual dibandingkan dengan pendekatan konvensional (tradisional).

Penerapan model pembelaaran kontekstual menyediakan lingkungan yang mendukung pembelajaran mandiri (self regulating learning) yang memiliki tiga karakteristik umum, yaitu kesadaran berfikir, penggunaan strategi, dan motivasi berkelanjutan, serta mempertimbangkan keragaman siswa (diversity of student). Di kelas guru harus mengajar siswa dengan berbagai keragaman misalnya latar belakang suku bangsa, status sosial ekonomi, bahasa, dan berbagai kekurangan yang mereka miliki. Aspek individual setiap siswa memperoleh perhatian yang cukup. Artinya jika setiap individu memperoleh layanan belajar yang memadai sesuai kebutuhannya, maka minat belajarnya pasti akan meningkat, dan pada akhirnya prestasi belajarnya juga meningkat.

Pembelajaran kontekstual dapat dikatakan sebagai sebuah model pembelajaran yang mengakui dan menunjukkan kondisi alamiah dari pengetahuan. Melalui hubungan di dalam dan di luar ruang kelas suatu pendekatan pembelajaran kontekstual menjadikan pengalaman lebih relevan dan berarti bagi siswa dalam membangun pengetahuan yang akan mereka terapkan dalam pembelajaran seumur hidup. Pembelajaran kontekstual menyajikan suatu konsep yang mengaitkan materi pelajaran yang dipelajari siswa dengan konteks dimana materi tersebut digunakan, serta berhubungan dengan bagaimana seseorang belajar atau gaya/cara siswa belajar. Konteks memberikan arti, relevansi, dan manfaat penuh terhadap belajar. 
Sebagai satu konsep pendekatan Contextual Teaching and Learning (CTL) memiliki tiga definisi. Pertama, CTL dapat didefinisikan sebagai mengajar dan belajar yang membantu guru menghubungkan mata pelajaran dengan situasi nyata dan memotivasi siswa agar menghubungkan pengetahuan dan terapannya dengan kehidupan sehari-hari sebagai anggota keluarga dan masyarakat. Kedua, CTL yaitu proses belajar mengajar yang erat kaitannya dengan pengalaman nyata. Ketiga, CTL dapat didefinisikan sebagai pembelajaran yang harus situation and cimentspecific dan memberi kesempatan dilakukannya pemecahan masalah secara riil atau otentik, serta latihan melakukan tugas.

Pembelajaran kontekstual bertujuan membekali siswa dengan pengetahuan yang secara fleksibel dapat diterapkan (ditransfer) dari satu permasalahan ke permasalahan yang lain dan dari satu konteks ke konteks lainnya. Transfer adalah kemampuan untuk berfikir dan beragumentasi tentang situasi baru melalui penggunaan pengetahuan awal. la dapat berkonotasi positif jika belajar atau pemecahan masalah ditingkatkan melalui penggunaan pengetahuan awal, dan berkonotasi negatif jika pengetahuan secara nyata menggangu proses belajar. Transfer dapat juga terjadi dalam suatu konteks melalui pemberian tugas yang terkait erat dengan materi pelajaran, atau antar dua atau lebih konteks di mana pengetahuan diperlukan dalam situasi tertentu, dan kemudian digunakan di dalam konteks yang lainnya. Dengan demikian jelaslah bahwa pembelajaran kontekstual Contextual Teaching and Learning) adalah konsep belajar yang membantu guru menghubungkan antara materi yang diajarkan dengan situasi dunia nyata siswa dan mendorong siswa membuat hubungan antara pengetahuan yang dimilikinya dengan penerapannya dalam kehidupan sehari-hari. Pembelajaran seperti dapat mendorong siswa untuk berpacu dan berprestasi, sehingga berpengaruh terhadap motivasi berprestasi siswa.

Di lain pihak quantum teaching juga memiliki keunggulan, yaitu: (1) pembelajaran quantum berpangkal pada psikologi kognitif, bukan fisika kuantum meskipun serba sedikit istilah dan konsep kuantum dipakai, (2) pembelajaran kuantum lebih bersifat humanistis, bukan positivistis-empiris, dan atau nativistis, (3) pembelajaran kuantum lebih konstruktivis, bukan positivistis empiris, behavioristis, (4) pembelajaran kuantum memusatkan perhatian pada interaksi yang bermutu dan bermakna, bukan sekedar transaksi makna, (5) pembelajaran kuantum sangat menekankan pada pemercepatan pembelajaran dengan taraf keberhasilan tinggi, (6) pembelajaran kuantum sangat menentukan kealamiahan dan kewajaran proses pembelajaran, bukan keartifisialan atau keadaan yang dibuat-buat, (7) pembelajaran kuantum sangat menekankan kebermaknaan dan kebermutuan proses pembelajaran, (8) pembelajaran kuantum memiliki model yang memadukan konteks dan isi pembelajaran, (9) pembelajaran kuantum memusatkan perhatian pada pembentukan ketrampilan akademis, ketrampilan (dalam) hidup, dan prestasi fisikal atau material, (10) pembelajaran kuantum menempatkan nilai dan keyakinan sebagai bagian penting proses pembelajaran, (11) pembelajaran kuantum mengutamakan keberagaman dan kebebasan, bukan keseragaman dan ketertiban, dan (12) pembelajaran kuantum mengintegrasikan totalitas tubuh dan pikiran dalam proses pembelajaran.

Hasil penelitian ini juga didukung oleh penelitian Ni Made Siwalatri, I Wayan Lasmawan, dan Nyoman Dantes dengan judul Pengaruh Pembelajaran Kontektual Berbantuan Media Gambar Terhadap Hasil Belajar IPS Ditinjau dari Motivasi Berprestasi siswa kelas IV SD Negeri 1 Semarapura Tengah. Penelitian ini menggunakan ANAVA dua jalur diuji dengan uji tukey.Sampel Penelitian ini berjumlah 84 orang siswa kelas IV dengan teknik random sampling .Hasil Penelitian menunjukkan bahwa: (1) terdapat peerbedaan hasil belajar siswa antara yang mengikuti model pembelajaran kontektual berbantuan media gambar dengan konvensional,dimana $\left(F_{\text {hitung }}=13,18 \cdot p<0,05\right)$. (2) terdapat interaksi antara penerapan model pembelajaran dengan motivasi berprestasi terhadap hasil belajar IPS, dimana(FAB (hitung $=46,64 \cdot p=0,05),(3)$ pada siswa yang memiliki motivasi berprestasi tinggi ,terdapat perbedaan hasil belajar IPS antara yang mengukuti model pembelajaran kontekstual berbantuan media gambar dengan konvensional ,dimana $(\mathrm{Q} 1=10,46>\mathrm{Qt}=2,86$ dengan taraf signifikansi $0,05)$,dan (4) pada siswa yang memiliki motivasi rendah ,terdapat perbedaan hasil belajar IPS antara yang mengikuti model pembelajaran kontektual berbantuan media gambar 
dengan konvensional dimana $(Q 2=3,20>Q t=2,86$ dengan taraf signifikasnsi 0,05$)$. Berdasarkan hasil temuan-temuan tersebut dapat disimpulkan bahwa terdapat pengaruh model pembelajaran kontektual berbantuan media gambar terhadap hasil belajar IPS ditinjau dari motivasi berprestasi siswa kelas IV SD negeri 1 Semarapura Tengah.

Berdasarkan uraian di atas tampak bahwa pembelajaran kontekstual dan quantum teaching memiliki keunggulan dan kelemahan. Tapi dilihat dari subtansi keunggulan tampaknya pembelajaran kontekstual memiliki keunggulan melebihi pembelajaran quantum, sehingga pembelajaran kontekstual memiliki hasil yang lebih daripada pembelajaran quantum dalam meningkatkan motivasi berprestasi siswa. Dengan demikian dapat disimpulkan bahwa ada perbedaan motivai berprestasi antara siswa yang diajar dengan pembelajaran kontekstual dan quantum teaching pada siswa kelas VII SMP Negeri 1 Kediri.

\section{Pengujian Hipotesi Kedua}

Berdasarkan hasil analisis dengan analisis varians satu jalur sebagaimana diperoleh nilai $F_{\text {hitung }}=30,384(p=0,000<0,05)$. Oleh karena itu, hipotesis nol $(\mathrm{Ho})$ yang menyatakan bahwa tidak perbedaan hasil belajar IPS siswa antara yang mengikuti pembelajaran dengan model pembelajaran Contextual Teaching and Learning dan Quantum Teaching pada siswa kelas VII SMP Negeri 1 Kediri. ditolak. Jadi, ada perbedaan hasil belajar IPS siswa antara yang mengikuti pembelajaran dengan model pembelajaran Contextual Teaching and Learning dan Quantum Teaching pada siswa kelas VII SMP Negeri 1 Kediri.

Hasil perhitungan menunjukkan bahwa hasil belajar IPS siswa yang mengikuti pembelajaran dengan model pembelajaran Contextual Teaching and Learning pada siswa kelas VII SMP Negeri 1 Kediri dengan skor rata-rata 85,300, sedangkan hasil belajar IPS siswa yang mengikuti pembelajaran dengan pembelajaran Quantum Teaching pada siswa kelas VII SMP Negeri 1 Kediri. dengan skor rata-rata 73,267. Ternyata skor rata-rata hasil belajar IPS siswa yang mengikuti pembelajaran dengan model pembelajaran Contextual Teaching and Learning lebih tinggi daripada sikap siswa yang mengikuti pembelajaran dengan pembelajaran Quantum Teaching pada siswa kelas VII SMP Negeri 1 Kediri. Dengan demikian, dapat disimpulkan hasil belajar IPS siswa yang mengikuti pembelajaran dengan model pembelajaran Contextual Teaching and Learning lebih tinggi daripada sikap siswa yang mengikuti pembelajaran dengan pembelajaran Quantum Teaching pada siswa kelas VII SMP Negeri 1 Kediri.

Pembelajaran dengan model pembelajaran CTL menekankan bahwa bagaimana seharusnya pembelajaran yang dikemas dengan pendekatan tersebut materinya secara nyata dapat dihadirkan dan dikaitkan dengan kehidupan sehari-hari siswa agar pembelajaran lebih bermakna. Siswa dalam pendekatan ini adalah sebagai pemeran utama, dimana siswa dapat mengkonstruksi pengetahuan yang dimilikinya, siswa dapat melakukan inquiry berdasarkan permasalahan yang disajikan, siswa dapat bertanya apa saja kepada guru maupun teman belajarnya, siswa dapat berkelompok membentuk masyarakat belajar, siswa dapat memahami materi melalui pemodelan yang dilakukan guru maupun temannya, siswa bersama guru dapat melakukan refleksi, serta guru dapat melakukan penilaian secara menyuluruh/otentik terhadap siswanya. Begitu halnya dengan pembelajaran konvensional, meskipun guru hanya dipandang sebagai pusat pembelajaran, namun jika cara guru menyampaikan materi dengan jelas dan dikaitkan dengan contoh dalam kehidupan nyata siswa, maka pembelajaran dengan pendekatan konvensional juga akan bermakna.

CTL dalam pendidikan merupakan pembelajaran yang menekankan pada pentingnya keterlibatan siswa dalam proses pembelajaran, untuk mencapai suatu keberhasilan secara individu maupun secara keseluruhan. Ini memberikan kesempatan pada siswa utuk menemukan jati dirinya (kemampuannya) dalam menghubungkan kegiatan yang dilakukan di sekolah dengan kehidupan mereka sehari-hari, serta mengembangk dan bakat menjadi informis, demokratis dalam masyarakat.

Johnson (2002:25) menjelaskan CTL merupakan suatu proses pendidikan yang bertujuan membantu siswa melihat makna dalam bahan pelajaran yang mereka pelajari 
dengan cara menghubungkannya dengan konteks kehidupan sehari-hari, yaitu dengan konteks lingkungan pribadinya, sosialnya, budayanya. Untuk mencapai tujuan tersebut, Strategi CTL akan menuntut siswa melalui delapan komponen utama CTL yakni melakukan hubungan yang bermakna, mengerjakan pekerjaan yang berarti, mengatur cara belajar sendiri, bekerja sama, berfikir kritis dan kreatif, memelihara/ merawat pribadi siswa, mencapai standar yang tinggi dan menggunakan penilaian yang sebenarnya. Kemudian Sagala (2003:57) CTL adalah konsep belajar yang membantu guru mengaitkan antara materi yang diajarkannya dengan situasi dunia nyata siswa dan mendorong siswa membuat hubungan antara pengetahuan yang dimilikinya dengan penerapannya dalam kehidupan mereka sehari-hari sehingga dapat dikatakan bahwa untuk mencapai tujuan pembelajaran, pembelajaran dengan model CTL lebih efektif jika dibanding dengan pembelajaran konvensional dalam pengaruhnya terhadap hasil belajar IPS siswa kelas VII SMP Negeri 1 Kediri.

Penelitian ini juga didukung oleh penelitian yang dilakukan oleh Penelitian yang dilakukan oleh Misrun Mauke, I Wayan Sadia dan I Wayan Suatra dengan judul Penerapan Model Contextual Teaching and Learning Terhadap Pemahaman Konsep dan Kemampuan Pemecahan Masalah dalam Pembelajaran IPA-Fisika di MTs Negeri Negara.Penelitian ini menggunakan rancangan"the posttest only control group design". Populasi penelitian ini siswa kelas VIII MTs Negeri Negara Tahun pelajaran 2012/2013.Sedangkan Sampel dalam penelitian ini terdiri dari dua kelas yang setara sebagai kelas eksperimen dengan pembelajaran model Contextual Teachi deskng Learning dan kelas control dengan pembelajaran model konvensional.Data pemahaman konsep dan kemampuan pemecahan masalah siswa diperoleh melalui tes essay.Data dianalisis secara Deskriptif dan MANOVA satu jalur. Hasil penelitian menunjukkan bahwa: (1) terdapat perbedaan yang signifikan antara pemahaman konsep dan kemampuan pemecahan masalah siswa yang mengikiti pembelajaran model Contextual Teaching And Learning MPK( $F=40,972 ; p<0,05)$. (2) Terdapat perbedaan yang signifikan antara siswa yang belajar menggunakanan model Contextual Teaching And Learning dengan MPK ( $F=36,053 ; p<0,05),(3)$ terdapat perbedaan yang signifikan antara siswa yang belajar menggunakan model peContextual Teaching And Learning dengan MPK ( $F=62,706 ; p 0,05)$, uji Scheffe menunjukkan bahwa model Contektual Teaching And Learning lebih baik dari MPK. Dengan demikian dapat dinyatakan bahwa pembelajaran kontekstual dan quantum teaching memberikan pengaruh yang berbeda terhadap motivasi berprestasi dan hasil belajar siswa kelas VII SMP Negeri 1 Kediri.

\section{Pengujian Hipotesi Ketiga}

Berdasarkan hasil analisis dengan manova sebagaimana disajikan pada Tabel 4.9, tampak bahwa nilai F- Wilks' Lambda $=48,307(p=0,000<0,05)$. Oleh karena itu, hipotesis $\mathrm{nol}(\mathrm{Ho})$ yang menyatakan bahwa tidak ada perbedaan motivasi berprestasi dan hasil belajar siswa antara yang mengikuti pembelajaran dengan model pembelajaran Contextual Teaching and Learning dan Quantum Teaching pada siswa kelas VII SMP Negeri 1 Kediri. ditolak. Jadi, terdapat perbedaan motivasi berprestasi dan hasil belajar siswa antara yang mengikuti pembelajaran dengan model pembelajaran Contextual Teaching and Learning dan Quantum Teaching pada siswa kelas VII SMP Negeri 1 Kediri.

Pembelajaran kontekstual dapat dikatakan sebagai sebuah model pembelajaran yang mengakui dan menunjukkan kondisi alamiah dari pengetahuan. Melalui hubungan di dalam dan di luar ruang kelas suatu pendekatan pembelajaran kontekstual menjadikan pengalaman lebih relevan dan berarti bagi siswa dalam membangun pengetahuan yang akan mereka terapkan dalam pembelajaran seumur hidup. Pembelajaran kontekstual menyajikan suatu konsep yang mengaitkan materi pelajaran yang dipelajari siswa dengan konteks dimana materi tersebut digunakan, serta berhubungan dengan bagaimana seseorang belajar atau gaya/cara siswa belajar. Konteks memberikan arti, relevansi, dan manfaat penuh terhadap belajar. 
Pembelajaran kontekstual bertujuan membekali siswa dengan pengetahuan yang secara fleksibel dapat diterapkan (ditransfer) dari satu permasalahan ke permasalahan yang lain dan dari satu konteks ke konteks lainnya. Transfer adalah kemampuan untuk berfikir dan beragumentasi tentang situasi baru melalui penggunaan pengetahuan awal. la dapat berkonotasi positif jika belajar atau pemecahan masalah ditingkatkan melalui penggunaan pengetahuan awal, dan berkonotasi negatif jika pengetahuan secara nyata menggangu proses belajar. Transfer dapat juga terjadi dalam suatu konteks melalui pemberian tugas yang terkait erat dengan materi pelajaran, atau antar dua atau lebih konteks di mana pengetahuan diperlukan dalam situasi tertentu, dan kemudian digunakan di dalam konteks yang lainnya. Dengan demikian jelaslah bahwa pembelajaran kontekstual Contextual Teaching and Learning) adalah konsep belajar yang membantu guru menghubungkan antara materi yang diajarkan dengan situasi dunia nyata siswa dan mendorong siswa membuat hubungan antara pengetahuan yang dimilikinya dengan penerapannya dalam kehidupan sehari-hari. Pembelajaran seperti dapat mendorong siswa untuk berpacu dan berprestasi, sehingga berpengaruh terhadap motivasi berprestasi siswa. Demikian pula motivasi berprestasi berpengaruh terhadap hasil belajar siswa.

Selain itu, model quantum teaching pada dasarnya membawa dunia kita ke dunia siswa. Konsep ini mengandung konsekuensi bahwa langkah pertama yang harus dilakukan guru dalam pelaksanaan pembelajaran adalah membangun jembatan autentik memasuki kehidupan siswa. Karena dengan tindakan ini akan memberikan izin kepada guru untuk memimpin, menuntun dan memudahkan perjalanan siswa menuju kesadaran yang lebih luas. Caranya dengan mengaitkan apa yang telah diajarkan dengan sebuah peristiwa, pikiran atau perasaan yang diperoleh dari kehidupan rumah, sosial, atletik, musik, seni, rekreasi, atau akademis mereka. Setelah kaitan ini terbentuk, guru dapat membawa mereka ke dalam dunianya serta memberi pemahaman akan misi dunia itu. Sehingga siswa dapat membawa apa yang mereka pelajari ke dalam dunianya dan menerapkannya pada situasi baru. Quantum teaching memberdayakan seluruh unsur yang ada dalam proses pembelajaran yang mencakup petunjuk-petunjuk untuk menciptakan lingkungan belajar yang baik, menyampaikan materi pembelajaran, memahami cara siswa menyerap informasi yang disampaikan dalam proses pembelajaran dan memudahkan proses pembelajaran.

Berdasarkan karakteristik yang ada di model pembelajaran kontekstual dan quantum teaching tampak sama-sama mengaitkan konsep yang ada dalam mata pelajaran dengan lingkungan atau kehidupan nyata, namun di pembelajaran kontektual lebih menekankan mengkonstruksi pengetahuan dan keterampilan secara mandiri. Bila dilihat hasil empiris menunjukkan bahwa pembelajaran kontekstual memberikan pengaruh yang lebih tinggi terhadap motivasi berprestasi dan hasil belajar IPS siswa dibandingkan dengan quantum teaching. Dengan demikian dapat dinyatakan bahwa pembelajaran kontekstual dan quantum teaching memberikan pengaruh yang berbeda terhadap motivasi berprestasi dan hasil belajar siswa kelas VII SMP Negeri 1 Kediri.

\section{SIMPULAN DAN SARAN}

Berdasarkan analisis dan pembahasan seperti yang telah dipaparkan pada bagian sebelumnya, maka dapat disimpulkan: (1) ada perbedaan motivasi berprestasi siswa antara yang mengikuti pembelajaran dengan model pembelajaran Contextual Teaching and Learning dan Quantum Teaching pada siswa kelas VII SMP Negeri 1 Kediri dengan Fhitung $=52,613(\mathrm{p}=0,000<0,05)$, (2) ada perbedaan hasil belajar IPS siswa antara yang mengikuti pembelajaran dengan model pembelajaran Contextual Teaching and Learning dan Quantum Teaching pada siswa kelas VII SMP Negeri 1 Kediri dengan Fhitung $=30,384(p=$ $0,000<0,05)$, dan (3) terdapat perbedaan motivasi berprestasi dan hasil belajar IPS siswa antara yang mengikuti pembelajaran dengan model pembelajaran Contextual Teaching and Learning dan Quantum Teaching pada siswa kelas VII SMP Negeri 1 Kediri dengan F- Wilks' Lambda $=48,307(p=0,000<0,05)$.

Hasil penelitian menunjukkan bahwa model pembelajaran Contextual Teaching and Learning dan quantum teaching berpengaruh secara terpisah maupun simultan terhadap 
motivasi berprestasi dan hasil belajar IPS siswa. Berdasarkan kesimpulan dan implikasi penelitian yang telah dipaparkan di atas, maka kepada guru disarankan menggunakan model pembelajaran Contextual Teaching and Learning dan quantum teaching sebagai upaya untuk meningkatkan motivasi berprestasi dan hasil belajar IPS siswa. Dalam kegiatan belajar mengajar di kelas, guru disarankan agar tidak hanya terfokus pada satu model pembelajaran saja agar peserta didik tidak cepat merasa bosan dalam kegiatan pembelajaran.

Kendala yang biasa dihadapi para guru dalam mencoba melakukan inovasi-inovasi adalah faktor siswa yang kurang responsif. Seringkali keinginan guru memberikan layanan terbaik buat siswa tidak ditanggapi secara maksimal bahkan siswa seringkali sudah menduga bahwa apa yang akan dilakukan para guru itu hanya akan menambah beban belajarnya. Atas dasar hal tersebut maka disarankan kepada para guru untuk bertindak tegas dan menjelaskan tujuan pembelajaran secara benar kepada siswa. Jika tidak, pembelajaran dengan Contextual Teaching and Learning dan quantum teaching justru akan lebih banyak menghabiskan waktu, disamping itu tujuan pembelajaran juga menjadi tidak terarah.

\section{DAFTAR RUJUKAN}

Bandono,2008.Menyusun Pembelajaran Contextual Teaching Learning.

De Porter. B. Reardon, M. Nourie, S. S. 2010. Quantum Teaching. Jakarta : Kaifa.

Fitriani. 2016. "Efektifitas Penerapan Model Pembelajaran Kooperatif Tipe Numbered Heads Togerther (NHT) Terhadap Motivasi dan Prestasi belajar Kimia Peserta Didik KelasX SMA Negeri 2 Yogyakarta Tahun Ajaran 2016/2017.

I Made Siwalatri,Prof I Wayan Lasmawan,M.Pd,Prof.Dr.Nyoman Dantes."Pengaruh Pembelajaran Berbantuan Media Gambar Terhadap Hasil Belajar IPS Ditinjau dari Motivasi Berprestasi siswa kelas IV SD Negeri 1 Semarapura Tengah".e-journal Program Pascasarjana Universitas Pendidikan Ganesha Progaram Studi Pendidikan.

Johnsos,Elaine B.2002.Contextual Teaching and Learning. What it is and Why it's Here To Stay.California:Corwin PRESS

Kemdikbud. 2016. Hasil uji Kompetensi Guru Tahun 2015. (http://www.kemdikbud.go.id/ diakses tanggal 12 Juni 2017).

Martaniah, Sri Mulyani. 1984. Motif Sosial Remaja Suku Jawa dan Keturunan Cina di Beberapa SMA Yogyakarta. Yogyakarta: Gadjah Mada University Press.

McClelland, D.C., Atkinson, J. W., Clark, R.A. and Lowell, E.L..1976. The achievvement Motive. New York: Irvington Publishers, Inc.

Misrun Mauke, I Wayan Sadia, I Wayan Suatra. 2013. "Pengaruh Model Pembelajaran Contextual Teaching and Learning Terhadap Pemahaman Konsep dan Kemampuan Pemecahan Masalah dalam Pembelajaran IPA- Fisika di MTs Negeri Negara". eJournal Program Pasca Sarjana Universitas Pendidikan Ganesha.Volume 3 Tahun 2013.

Nurhadi. 2003. Pendekatan Kontekstual. Jakarta: Dirjen Dikdasmen Depdiknas.

Sardiman, A.M. 2010. Interaksi \& Motivasi Belajar Mengajar. Jakarta: PT Raja Grafindo Persada. 
Sukari. 1999. "Studi Korelasional antara Persepsi Widyaiswara terhadap Jabatannya dan Motivasi Berprestasi dengan Kinerja Widyaiswara”. Dalam Jurnal Teknologi Pendidikan Volume 1, nomor 1 (hlm.48-70).

Yulianti, Linda Dwi. 2015. "Kendala Guru Mengajar IPS di SMP Swasta pada Kecamatan Natar Tahun Pelajaran 2014/2015". Skripsi (tidak diterbitkan), Lampung: Universitas Lampung.

Sagala, Saiful. 2010. Konsep dan Makna Pembelajaran untuk Membantu Memecahkan Problematika Belajar dan Mengajar. Bandung: Alfabeta.

https://www.kompasiana.com, diakses tanggal 12 Januari 2018 